\title{
Breaking the Silence: Why International Organizations Should Acknowledge Customary International Law Obligations to Provide Effective Remedies
}

\author{
Kristina Daugirdas and Sachi Schuricht*
}

\begin{abstract}
To date, international organizations have remained largely silent about their obligations under customary international law. This chapter urges international organizations to change course, and to expressly acknowledge customary international law obligations to provide effective remedies. Notably, international organizations' obligations to afford effective remedies need not precisely mirror States' obligations to do so. Instead, international organizations may be governed by particular customary international law rules. By publicly acknowledging obligations to afford effective remedies, international organizations can influence the development of such particular rules. In addition, by acknowledging obligations to afford effective remedies - and by actually providing effective remedies - international organizations can rebut arguments that they are above the law, and can help to retain support for their jurisdictional immunities.
\end{abstract}

Individuals and other private actors who have been harmed by international organizations usually will not get very far if they seek recourse in national courts. Immunity typically shields international organizations from such legal

* Kristina Daugirdas, Professor of Law at the University of Michigan Law School, kdaugir@ umich.edu; Sachi Schuricht, Associate at Orrick, Herrington \& Sutcliffe, LLP, sschur@umich. edu. The views presented in this chapter are those of the authors alone and do not necessarily represent the views of the firm or its clients. The authors would like to thank Monica Hakimi, Steve Ratner, and Peter Quayle for their helpful comments.

(C) ASIAN INFRASTRUCTURE INVESTMENT BANK (AIIB), 2021 | DOI:10.1163/9789004441033_004

This is an open access chapter distributed under the terms of the CC-BY-NC 4.0dicense. 
process. ${ }^{1}$ In some cases, these private actors have recourse to other forums or mechanisms for resolving disputes and challenging the conduct of international organizations. Employees of individual organizations can turn to administrative tribunals. ${ }^{2}$ Parties who have entered into contracts with international organizations may be able to invoke the arbitration or other dispute resolution mechanisms written into their contracts. ${ }^{3}$ Individuals harmed by the acts or omissions of multilateral development banks may be able to turn to specialized accountability mechanisms like the World Bank Inspection Panel (WBIP). ${ }^{4}$ Individuals subject to the United Nations (UN) Security Council's ISIL and Al-Qaida targeted sanctions regime may enlist the Office of the Ombudsperson to challenge their designation. ${ }^{5}$ But many individuals harmed outside of the employment and commercial contexts do not have any avenue to seek recourse from international organizations.

There are many policy reasons for international organizations to develop alternative dispute resolution mechanisms to fill this remedial gap. Back in 1954, the International Court of Justice (ICJ) observed that establishing an administrative tribunal,

to do justice between the [United Nations] and its staff members was essential to ensure the efficient working of the Secretariat, and to give effect to the paramount consideration of securing the highest standards of efficiency, competence, and integrity. ${ }^{6}$

Several decades later, Ibrahim Shihata, the former General Counsel of the World Bank, argued that the WBIP would improve "the efficiency of the Bank and of development finance in general. ${ }^{7}$ Finally, as international organizations'

1 Benvenisti, The Law of Global Governance 2014, 96 ("IGOs enjoy absolute immunity from national courts, granted to them either in headquarters agreements with host States or in the constituent treaties that bind all State parties").

2 Kingsbury and others 2005, 20; Benvenisti, The Law of Global Governance 2014, 168-171.

3 Schmitt 2017, 179-183.

4 Suzuki and Nanwani 2005, 206-219.

5 See United Nations Security Council (UNSC), 'Ombudsperson to the ISIL'.

6 ICJ, Effect of Awards 1954, 57.

7 Shihata 1994, 114-115 ("[T] he mere presence of the Panel is likely to make the Bank staff more diligent in the observance of Bank policies. [...] Since these policies and procedures are meant to ensure quality in the Bank-financed projects and to serve broader institutional objectives approved by Bank members (through the Executive Directors), the greater attention paid to them can only serve the Bank, its members as a whole, and in particular the borrowers concerned. Inspection can also raise issues not otherwise known or appreciated and may cause the Bank to adopt more effective or clearer standards in the pursuit of its objectives. In 
lawyers have themselves recognized, international organizations' immunity is vulnerable when injured individuals lack access to alternative dispute settlement mechanisms. ${ }^{8}$

In addition, international organizations may have legal obligations to develop such mechanisms. One possible source of such obligations is customary international law. Section 2 explains that there is a strong argument that customary international law binds international organizations. That said, scholars of international law continue to debate whether all or only some customary rules bind international organizations. Moreover, international organizations have been, on the whole, conspicuously reluctant to acknowledge these obligations in public statements. In any event, applying customary international law norms to international organizations is not entirely straightforward. In some cases, rules that were developed mainly by and for States must be adapted to account for differences between international organizations and States and for differences among international organizations.

Section 3 addresses States' obligations to afford effective remedies to individuals who have been harmed by violations of human rights law. This section considers the extent to which these obligations have hardened into customary international law and, if so, what exactly they require of States. As evidenced by States' treaty obligations, effective remedies have both procedural and substantive elements. The precise contours of the obligations, however, are not well defined and States retain significant discretion in crafting such remedies. Moreover, effective remedies are not 'one size fits all'; the necessary components will depend to some degree on which right is violated and the gravity of the violation.

Section 4 considers how an obligation to provide effective remedies might apply to-and be adapted for-international organizations. International organizations' customary law obligations need not precisely mirror States' obligations. Instead, international organizations may be governed by particular customary international law rules. Most significantly, this section argues that

the process, it can enhance the awareness of the borrowers of deficiencies in their own processes and attitudes that need to be corrected [...]. The end result should increase the efficiency of the Bank and of development finance in general"). See also Benvenisti, The Applicability of the Law of Occupation 2019 (focusing on UN-led instances of territorial administration and arguing that "accountability is not a burden on functionality. Rather, accountability enhances functionality, and in fact, it is necessary for ensuring functionality").

8 See, for example, Amerasinghe 1982; Kwakwa 2010, 600; Martha 2012, 93-94; ibid, 125 ("[M] ost of the calls for eliminating or restricting the immunities of international organizations invoke the absence of alternative dispute-settlement mechanisms for noncontractual disputes in order to justify why the concept of immunity is anathema to the concept of fair play and substantial justice"). 
the scope of international organizations' obligations to provide effective remedies may well be broader than those of States for two reasons. Such particular customary rules may build on treaty obligations that require international organizations to develop alternative dispute settlement mechanisms in cases that do not necessarily involve a violation of international law. In addition, such norms may develop from the practice of international organizationslike the WBIP and similar institutions at other multilateral development banks - that likewise provide remedies to individuals who have been harmed in instances that may not involve a violation of international law.

Section 5 urges international organizations to not only afford effective remedies - but to expressly acknowledge a customary international law obligation to do so. The International Law Commission (ILC) recently affirmed that international organizations can contribute to the development of customary international law. ${ }^{9}$ By speaking out about their obligations to afford effective remedies, international organizations can actively shape the development of customary international law in this area. Moreover, such engagement can help to ensure the sustainability of international organizations' immunities. The perception that international organizations are above the law erodes their legitimacy — and in particular, support for their immunity. ${ }^{10}$ By publicly acknowledging legal obligations to afford effective remedies-and ensuring that they do indeed provide effective remedies-international organizations can better defend against such charges.

\section{2 \\ International Organizations' Obligations Under Customary International Law}

In some cases, international organizations have express treaty obligations to develop alternative mechanisms for resolving disputes that cannot be resolved by national courts on account of their jurisdictional immunity. ${ }^{11}$ Often,

$9 \quad$ ILC, 'Draft Conclusions on Identification of Customary International Law' 2018, conclusion 4(2) ("In certain cases, the practice of international organizations also contributes to the formation, or expression, of rules of customary international law").

10 Boon 2016, 375 ("[A]s a matter of public legitimacy, the UN must not be seen to be above the law"); Daugirdas, 'Reputation and Responsibility' 2014, 1007-1009. For examples in the popular press, see Yeoman, 27 September 2018; Rosen, 26 February 2013 ("The organization is functionally above the law - and victims of Haiti's cholera outbreak aren't the only ones paying the price").

11 Convention on the Privileges and Immunities of the United Nations (General Convention), art VIII, s 29; Convention on the Privileges and Immunities of the Specialized Agencies (Specialized Agencies Convention), art IX, s 31; see also Berenson 2012, 139 (describing multilateral and bilateral agreements that the Organization of American States has 
however, such treaty obligations are limited or nonexistent. As a result, any cross-cutting obligation to afford effective remedies must come from another source of law. The most promising candidate is customary international law. ${ }^{12}$ But to what extent does customary international law bind international organizations? It turns out that the answer to this question remains somewhat contested.

Arguments that customary international law binds international organizations often reference a 1980 advisory opinion of the ICJ concerning the legality of efforts to relocate the regional office of the World Health Organization (wHo) in Alexandria, Egypt. ${ }^{13}$ Egypt had protested that the proposed relocation would violate a 1951 bilateral treaty between itself and the wHO. In the course of a paragraph that makes the obviously correct and rather trivial point that international organizations lack an absolute right to select the location of their offices, the Court wrote:

International organizations are subjects of international law and, as such, are bound by any obligations incumbent upon them under general rules of international law, under their constitutions or under international agreements to which they are parties. ${ }^{14}$

Paraphrasing this sentence, many scholars have affirmed that customary international law binds international organizations. ${ }^{15}$ Others have expressed doubts, citing the lack of practice to support this conclusion, or taking the position that the ICJ was referring to only a subset of customary international law rules. ${ }^{16}$ After all, the statement that international organizations are bound by

concluded); Reinisch, 'Immunity' 2008, 288 (describing the International Atomic Energy Agency's headquarters agreement with Austria).

12 The charters of individual organizations may also be sources of such obligations; so too may be other international agreements to which organizations are parties, such as the specialized agencies' relationship agreements with the United Nations. See, for example, Verdirame 2011; Skogly 2001. The literature on global administrative law suggests some possibilities outside the traditional sources of international law. See Benvenisti, The Law of Global Governance 2014, 91-137 (suggesting that such principles are binding based on 'rule of law' principles, international human rights law, or trusteeship); Kingsbury and others 2005, 29 (proposing a 'revived version of ius gentium').

13 ICJ, Interpretation of the Agreement Between the wHO and Egypt 1980.

14 Ibid, para 37.

15 See Reinisch, 'Accountability' 2001, 136; Brunnée 2005, 40; Benvenisti, The Law of Global Governance 2014, 99; Shelton 2015, 46.

16 Alvarez 2007, 677; Klabbers 2017, 987; see also Wellens 2002, 1 ("As subjects of international law, international organizations $[\ldots]$ are subject to rules and norms of customary international law to the extent required by their functional powers $[\ldots]$ "). 
"any obligations incumbent upon them under general rules of international law" leaves open the question of which obligations so qualify. ${ }^{17}$

For their part, most international organizations have said little or nothing about whether and to what extent customary international law binds them. ${ }^{18}$ They have neither expressly rejected nor acknowledged the applicability of customary international law other than jus cogens norms. ${ }^{19}$

Some international organizations weighed in on this question several decades ago during the deliberations over the set of draft articles adopted by the ILC that were eventually codified as the 1986 Vienna Convention on the Law of Treaties Between States and International Organizations or Between International Organizations. ${ }^{20} \mathrm{~A}$ number of organizations sought to ensure that any rules resulting from this process could not bind them without their consent. ${ }^{21}$ Some advocated against negotiating a treaty at all. Instead, they proposed that the General Assembly adopt the Commission's draft articles "as a standard of reference for action destined to harden into customary international law". 22 This proposal indicates that these organizations understood such customary rules would bind them; otherwise, their proposal does not make sense.

More recently, the ILC's development of draft articles regarding the responsibility of international organizations provided another opportunity for international organizations to address their obligations under customary international law. The final set of articles, adopted in 2011, includes a provision that describes the elements of an internationally wrongful act of an international organization, indicating that there is such an act when "conduct consisting of an action or omission: (a) is attributable to that organization under international law; and (b) constitutes a breach of an international obligation of that

17 ICJ, Interpretation of the Agreement Between the wHO and Egypt 1980, para 37 (emphasis added).

18 Daugirdas, 'How and Why' 2016, 372-380; see also Benvenisti, The Applicability of the Law of Occupation 2019, 3-4 (describing the United Nations' silence with respect to the legal framework that applies to UN-led administration of territories); Wellens 2002 (noting a long-established "reluctance by international organizations to acknowledge in explicit terms a legal obligation to comply with human rights").

19 As defined by the Vienna Convention on the Law of Treaties (VCLT), art 53, a jus cogens or peremptory norm is "a norm from which no derogation is permitted and which can be modified only by a subsequent norm of general international law having the same character". See also Frowein, 2013. 
organization". ${ }^{23}$ The commentary elaborated on this second element, noting that the breached obligation may "result from either a treaty binding the international organization or from any other source of international law applicable to the organization". ${ }^{24}$ The commentary then quotes the same indeterminate sentence from the WHO-Egypt advisory opinion, and notes that a "breach is possible with regard to any of these international obligations"25 — that is, the obligations "incumbent upon [international organizations] under general rules of international law, under their constitutions or under international agreements to which they are parties". ${ }^{26}$ Thus, the ILC did not stake out a position on the question of which customary international law rules bind international organizations.

In their comments to the ILC, participating international organizations generally agreed that jus cogens norms bind them. A handful said so explicitly, and none contested this conclusion. ${ }^{27}$ When it came to other customary international law norms, however, the organizations that submitted comments did not embrace their application. No organizations directly rejected the view that customary international law binds them-but none directly acknowledged such obligations either. ${ }^{28}$ Some organizations did suggest that customary international law had virtually no relevance for international organizations because their charters reflect lex specialis-or specific rules that displace the more generally applicable rules regarding the responsibility of international organizations. ${ }^{29}$ Take, for example, these comments by the International Monetary Fund:

23 ILC, 'Draft Articles on Responsibility of International Organizations' 2011, art 4.

24 Ibid, art 4, comm (2).

25 Ibid.

26 Ibid.

27 Daugirdas, 'How and Why' 2016, 378-379 and n 301 (quoting comments from the International Monetary Fund, the Organization for Economic Cooperation and Development, the Organization for Security and Cooperation in Europe, and the World Bank).

28 For a more detailed discussion of international organizations' comments, see Daugirdas, 'How and Why' 2016, 377-380.

29 The lex specialis principle provides that when both a general and a more specific rule govern the same subject matter, the specific rule should take precedence over the more general rule. Koskenniemi 2006, para 6o ("A special rule is more to the point [...] than a general one and it regulates the matter more effectively [...] than general rules. This could also be expressed by saying that special rules are better able to take account of particular circumstances. The need to comply with them is felt more acutely than is the case with general rules. They have greater clarity and definiteness and are thus often felt 'harder' or more 'binding' than general rules which may stay in the background and be applied only rarely. Moreover, lex specialis may also seem useful as it may provide better access to what the parties may have willed”). See also Daugirdas, 'How and Why' 2016, 347-348. Note that 
[W]hen an organization acts in accordance with the terms of its constituent charter, such acts can only be wrongful in relation to another norm of international law if the other norm in question is either a "peremptory norm" (jus cogens) or arises from a specific obligation that has been incurred by the organization in the course of its activities ([for example], by entering into a separate treaty with another subject of international law). However, vis-à-vis all other norms of international law, both the charter and the internal rules of the organization would be lex specialis as far as the organization's responsibility is concerned and, accordingly, cannot be overridden by lex generalis, which would include the provisions of the draft articles. ${ }^{30}$

It would be a mistake to interpret these comments as implying a categorical rejection of the view that customary international law binds international organizations. ${ }^{31}$ First, the lex specialis argument is limited to relations between international organizations and their member States: it does not affect the point that customary international law governs relations between international organizations and non-member States. Second, it is important to keep in mind that when States create lex specialis, they are not necessarily rejecting general international law. Sometimes lex specialis is an elaboration or specification of an already-applicable, general international law rule. And even when States do create lex specialis to diverge from otherwise-applicable general international law, general international law norms persist in the background. Those norms fill gaps and influence the interpretation of treaties-including constituent instruments that establish international organizations. Finally, treaties that create lex specialis are presumed to align with customary international law unless States have made clear their desire to diverge from it. ${ }^{32}$ As a result, these rules are already implicit in international organizations' charters except to the extent that their charters provide to the contrary.

In this context, the Asian Infrastructure Investment Bank (АІІВ) is a refreshing — and admirable—counterexample. The AIIB website includes the following statement:

there are some limitations on States' capacity to derogate from customary international law by creating lex specialis. Ibid, $346-347$. other examples of similar statements, see Daugirdas, 'How and Why' 2016, 378-379.

31 Daugirdas, 'How and Why' 2016, 379-380.

32 Ibid, 348. 
AIIB is an international organization established by the AIIB Articles of Agreement (entered into force on December 25, 2015), a multilateral treaty, the Parties to which comprise the Membership of the Bank. Accordingly, АІ в is both constituted and governed by public international law, the sources of which include applicable international conventions, customary international law, general principles of law and subsidiary means for the determination of rules of law. ${ }^{33}$

Just as the ICJ's WHO-Egypt opinion raised questions about which rules are 'incumbent upon' international organizations, the AIIB's statement on international law leaves unaddressed the question of which customary international law rules are 'applicable' to the Агів. But the acknowledgement of at least some customary international law obligations is notable nonetheless.

In prior work, one of the present authors sought to supply a firmer foundation for the conclusion that the entire corpus of customary international law does indeed bind international organizations, at least as a default matter. ${ }^{34}$ The argument goes, in short, that this conclusion holds regardless of whether one conceives of international organizations as peers of States on the international plane (that is, as entities that exercise independent authority as both a formal legal matter and as a practical matter $)^{35}$ or as vehicles through which States act. ${ }^{36}$ The reasons for the conclusion differ, however. On the peer view, customary international law automatically binds international organizations, just as it binds new States, by virtue of their status as members of the international community. ${ }^{37}$ From the vehicle perspective, the underlying concern is that States will try to evade their international obligations by acting through international organizations. Here, treaty law supplies the relevant baseline: what States can do directly by treaty, they can do indirectly through an international organization. And what States cannot do directly by treaty, they cannot do indirectly through an international organization. ${ }^{38}$ Thus, States cannot create international organizations that are unbound by customary international law vis-à-vis non-member States because the pacta tertiis rule precludes States from using treaties to modify their international obligations to non-parties. ${ }^{39}$ States can use treaties to create lex specialis and modify their customary

33 АІІв, 'The Role of Law'.

34 Daugirdas, 'How and Why' 2016, 325.

35 See ibid, $359-365$.

36 Ibid, 345 .

37 See ibid, $357-359$ and $365-368$.

38 Ibid, 345 .

39 The pacta tertiis rule is codified in the VCLT, art 34 ("A treaty does not create either obligations or rights for a third State without its consent"). See also Chinkin 1993, 71 ("Treaties 
international law obligations to other parties-but, as noted above, treaties are generally interpreted to align with customary international law unless States have made clear their desire to diverge from it. ${ }^{40}$ Thus, when it comes to an international organization's interactions with its member States, customary international law binds the organization except to the extent that the member States have clearly expressed their desire for the organization to diverge from it. ${ }^{41}$ In sum, customary international law binds international organizations to the same degree that it binds States: international organizations are not more extensively or more readily bound, nor are they less extensively or less readily bound.

\section{$3 \quad$ States' Obligations to Afford Effective Remedies}

Numerous international human rights treaties expressly require States to afford effective remedies to victims of human rights violations. There is a plausible, albeit not uncontested, argument that over the past several decades this obligation has - in at least some contexts - ripened into a norm of customary international law.

As a starting point, article 8 of the Universal Declaration of Human Rights (UDHR) provides that "[e]veryone has the right to an effective remedy by competent national tribunals for acts violating the fundamental rights granted him by the constitution or by law". ${ }^{42}$ Although the status of the UDHR as a binding source of international law is unsettled, ${ }^{43}$ it is foundational to many other human rights instruments. Among those is the International Covenant on Civil and Political Rights (ICCPR), which similarly obligates each State party to provide effective remedies for violations of rights protected by that instrument. Article 2(3) reads:

Each State Party to the present Covenant undertakes:

(a) To ensure that any person whose rights or freedoms as herein recognized are violated shall have an effective remedy notwithstanding

bind consenting parties only, and strangers to any treaty are legally unaffected by it. This is the classic rule of treaties and third parties [...]").

40 Daugirdas, 'How and Why' 2016, 347-348.

41 Ibid.

42 Universal Declaration of Human Rights (UDHR), art 8.

43 Hannum 1996, 317-335 (summarizing varying customary treatment of the UDHR, whereby some States treat all of the articulated rights as customary international law while others consider only some of them binding). 
that the violation has been committed by persons acting in an official capacity;

(b) To ensure that any person claiming such a remedy shall have the right thereto determined by competent judicial, administrative or legislative authorities, or by any other competent authority provided for by the legal system of the State, and to develop the possibilities of judicial remedy;

(c) To ensure that the competent authorities shall enforce such remedies when granted. ${ }^{44}$

\section{Similar guarantees are found in other human rights treaties. ${ }^{45}$}

Surveys of State practice have reached inconsistent results as to whether States consistently provide effective remedies for violations of human rights, and whether they do so with a sense of legal obligation. One survey of State practice in 1995 indicated that the right to an effective remedy was "not generally included in lists of customary human rights and [was] not the subject of significant domestic jurisprudence". ${ }^{46}$ Likewise, in 2001, another scholar took the view that,

44 International Covenant on Civil and Political Rights (ICCPR), art 2(3).

45 See European Convention for the Protection of Human Rights and Fundamental Freedoms (ECHR), art 13 (guaranteeing to "[e]veryone whose rights and freedoms as set forth in this Convention are violated [...] an effective remedy before a national authority"); Convention on the Elimination of All Forms of Racial Discrimination, art 6 (obligating state parties to assure "effective protection and remedies, through the competent national tribunals and other State institutions [...] as well as the right to seek from such tribunals just and adequate reparation or satisfaction"); American Convention on Human Rights, art 25 ("Everyone has the right to simple and prompt recourse, or any other effective recourse, to a competent court or tribunal for protection against acts that violate his fundamental rights"; obliging state parties "(a) To ensure that any person claiming such remedy shall have his rights determined by the competent authority provided for by the legal system of the state; (b) To develop the possibilities of judicial remedy; and (c) To ensure that the competent authorities shall enforce such remedies when granted"); Charter of Fundamental Rights of the European Union, art 47 ("Everyone whose rights and freedoms guaranteed by the law of the Union are violated has the right to an effective remedy before a tribunal $[\ldots]$ "). For a comprehensive discussion of relevant human rights instruments, see Shelton $2015,63-73$.

46 Hannum 1996, 345; see ibid, 329-335 (noting that governments of the US, Denmark, Switzerland, Australia and New Zealand had not specified whether article 8 of the UDHR counts among the rights therein that qualify as customary international law, while officials from Singapore, China and Germany (and a court from South Africa) had made statements according less-than-binding status to the entire UDHR). 
treaty practice as such does not yet provide a sufficiently broad basis for the conclusion that today access to effective judicial or administrative proceedings is an entitlement enshrined in general, [which is to say], customary international law. ${ }^{47}$

However, other scholars have surveyed State practice over largely the same period and concluded that States do recognize "the duty to provide a remedy to victims' of human rights violations". ${ }^{48}$ Notably, the most recent and comprehensive review of human rights remedies, completed by Dinah Shelton in 2015, recognizes that "national tribunals [are] hear[ing] and decid[ing] more cases alleging violations of international human rights norms", 49 "as states have increasingly limited their governmental immunities and developed innovative responses to human rights violations". ${ }^{50}$ Extensive work in this area led Shelton to conclude that " $[t]$ he right to a remedy is well established, even a norm of customary international law".51 Other scholars, and some international courts, have reached the similar conclusion that treaty-based rights to remedies reflect customary international law rules. ${ }^{2}$

If it is a customary international law norm, what does the obligation to provide an effective remedy require of States? International human rights instruments that articulate a right to an effective remedy tend to employ vague terms

$47 \quad$ Handl 2001, 52.

48 Bassiouni 2006, 218-221(surveying contemporary state practice as reflected in constitutions, legislative proposals, and legal systems). The inconsistencies among these surveys may be due to changes over time and to the authors' consideration of different source materials. For instance, Bassiouni's survey included proposed legislation that had not yet been adopted by several States (Ibid, 218, n 67).

49 Shelton $2015,91$.

$50 \quad$ Ibid, 141.

51 Ibid, 238.

52 See Inter-American Court of Human Rights (IACtHR), Aloeboetoe v Suriname (Reparations) 1993, para 43 (describing Article 63(1) of the American Convention on Human Rights, which requires remedies for violations of human rights, as a codified rule of customary law); cf Permanent Court of International Justice (PCIJ), Case Concerning the Factory at Chorzów 1927, 21 (describing the obligation to make adequate reparations as "a principle of international law" which applies regardless of its express articulation in a treaty). See also Reinisch, 'Immunity' 2008, 287 (suggesting that the obligation to provide a legal remedy is "implicitly contained in the customary international law prohibition of a denial of justice"); Bradlow, 'Shield as a Sword' 2017, 60-61; International Commission of Jurists 2018, 19 (noting that the "obligation is enshrined in so many international human rights treaties, and confirmed by international jurisprudence, that it can be considered to be an obligation of customary international law"). 
and do not enunciate specific modalities for providing recourse. ${ }^{53}$ While States have considerable discretion to design remedial mechanisms, it is clear that an effective remedy encompasses both procedural and substantive elements. ${ }^{54}$ Many human rights instruments refer specifically to both procedural mechanisms and substantive reparations. ${ }^{55}$ Some, most notably the ICCPR, do not explicitly require substantive reparations, but UN treaty bodies have understood even a general reference to an "effective remedy" as encompassing both procedural and substantive relief. ${ }^{56}$ As scholars have observed, these two elements are complementary: "a right of reparation is [...] an empty victory if there is no corresponding mechanism to provide [...] a forum to press a claim or obtain an award". 57

Importantly, what qualifies as an effective remedy will depend on the right that is violated, as well as on the gravity of the violation. ${ }^{58}$ With respect to procedural relief, some instruments refer specifically to the development of judicial remedies. ${ }^{59}$ However, most refer more broadly to the provision of

53 See Lasco 2003, 3 (observing that "many international human rights instruments [...] provide rights in vague terms that allow each state to interpret 'remedy' as it sees fit").

54 Shelton 2015, 58 ("Most texts guarantee both the procedural right of effective access to a fair hearing and the substantive right to a remedy"). The former element is often referred to as 'the right of access to justice' and the latter as 'substantive redress'. Ibid, 17. However, some scholars understand these terms - and their relationships to one anotherdifferently. See Schmitt 2017, 92-95 (discussing various conceptions of the right of access to justice, and positing that "the right of access to justice [...] concentrates on the procedural aspect while the [right to a remedy] focuses on the substantive result of the proceedings").

55 ECHR, art 6.

56 Human Rights Committee (HRC), 'General Comment No 31' 2004, para 16 (as explained by the HRC in its interpretation of ICCPR, art $2(3)$, " $[\mathrm{w}]$ ithout reparation to individuals whose Covenant rights have been violated, the obligation to provide an effective remedy [...] is not discharged"); PCIJ, Case Concerning the Factory at Chorzów 1927, 21 (the PCIJ employed similar logic nearly a century ago, when it explained that the obligation to provide substantive reparations need not be spelled out in a treaty, for it is "the indispensable complement of a failure to apply" protections that are expressly articulated in a binding text).

57 Bassiouni 2006, 232; see also ibid ("One of the cornerstones of a victim's right to reparations is that States have an obligation to have some form of mechanism in place to redress violations of their international and domestic legal obligations").

$5^{8}$ See International Law Association (ILA) 2004, 37 (noting that "the procedural aspects of remedial action will vary amongst the different categories of potential claimants"); International Commission of Jurists 2018, 77 (citing cases where the European Court of Human Rights (ECtHR) held that the right to a remedy, in ECHR, art 13, does not require a judicial remedy in all instances; rather, "the scope of the remedy varies with the right" at stake).

59 See ICCPR, art 2(3)(b); UNGA, 'Basic Principles' 2005, princ 12 (recognizing "access to an effective judicial remedy" as part of the right to remedies); see also Shelton 2015, 96 
'competent' tribunals, ${ }^{60}$ which may include judicial, administrative or legislative authorities - or a combination thereof. ${ }^{61}$ Whatever the nature of the tribunal, in order to provide effective procedural relief, the tribunal should be independent and impartial, ${ }^{62}$ widely accessible ${ }^{63}$ and capable of processing

("Access to justice means ensuring the possibility for an injured individual or group to bring a claim before an appropriate tribunal and have it adjudicated, increasingly this means by judicial proceedings").

6o See UDHR, art 8; Convention on the Elimination of All Forms of Racial Discrimination, art 6 (referring to "competent national tribunals and other State institutions"); Convention on the Elimination of All Forms of Discrimination against Women, art 2(c) (referring to "competent national tribunals and other public institutions").

61 HRC, 'General Comment No 31' 2004, para 15 (various UN treaty bodies have espoused a combination approach. For instance, in its interpretation of ICCPR, art 2(3), the HRC stressed the importance of establishing both judicial and administrative mechanisms, the latter of which "are particularly required to give effect to the general obligation to investigate allegations of violations promptly, thoroughly and effectively through independent and impartial bodies"); Committee on the Rights of the Child (CRC), 'General Comment No 16' 2013, para 71 (as another example, in General Comment No 16 on State Obligations Regarding the Impact of the Business Sector on Children's Rights, the CRC stated that “[n] on-judicial mechanisms, such as mediation, conciliation and arbitration, can be useful alternatives" to judicial process, but should be provided "without prejudice to the right to judicial remedy").

62 See Bradlow, 'Amicus Brief', 17 August 2016, 20-21 (reviewing the ECtHR's decisions about "reasonable alternative means of remedy" and concluding that qualifying forums are consistently 'independent' and 'impartial'); International Commission of Jurists 2018, 16 and 52; see also Shelton 2015, 96 ("[Access to justice] means the right to seek a remedy before a tribunal which is constituted by law and which is independent and impartial in the application of the law"); ibid, 100-102 (discussing the meaning of independence and impartiality in the context of international human rights law); Schmitt 2017, 108 (proposing "core institutional requirements" of the right of access to justice, including "the right to an independent and impartial 'tribunal' established by law").

63 To ensure accessibility, information about the accountability mechanism should be distributed widely and resources should be allocated so that barriers (often a lack of financial resources or expertise) do not prevent those harmed from accessing procedural remedies. See, for example, HRC, 'General Comment No 32' 2017 (interpreting ICCPR, art 14 to require equality of access and equality of arms); UNGA, 'Basic Principles' 2005, princ 12(a)-(d), 24 (encouraging states to publicly and privately disseminate information about available remedies and to provide assistance to victims to ensure that they can exercise their rights to remedies); see also International Commission of Jurists 2018, 71 (noting "a tendency towards recognition [...] that an effective remedy implies a positive obligation ... to assist those persons who do not have the means to access justice"); Bassiouni 2006, 26o-263 (discussing the duty on states to make known the availability of remedies for human rights violations and to ensure that victims can exercise their rights to such remedies); Shelton 2015, 98 (observing that "most human rights tribunals have held that if the failure to provide legal aid interferes with the right to pursue legal remedies $[\ldots]$ it is itself a human rights violation"). 
claims promptly. ${ }^{64}$ Finally, the tribunal should be empowered to render more than merely advisory opinions or recommendations. ${ }^{65}$

Much like the procedural component of the remedy, the nature of effective substantive relief depends on the circumstances of a given case. ${ }^{66}$ To a significant degree, the substantive component of an effective remedy tracks the elements of reparations required for violations of international law. ${ }^{67}$ An effective remedy may involve restitution, or relief that restores the claimant to the same position occupied prior to the wrong; this is generally considered the most effective substantive remedy. ${ }^{68}$ When that is not possible, compensation can cover the cost imposed by the wrong. ${ }^{69}$ If those remedies are not effective, or if the wrong is particularly blameworthy, rehabilitation or satisfaction-such as a public apology, acknowledgment of misconduct, or expression of regretmay be appropriate..$^{70}$ For example, in the case of repeat or widespread wrongs, effective substantive remedies might include a guarantee of non-repetition or

64 See, for example, UNGA, 'Basic Principles' 2005, princ 11(b); International Commission of Jurists 2018, 66 (reviewing ECtHR jurisprudence on the importance of promptness); Shelton 2015,102 ("The speed with which a remedy can be obtained may be relevant in assessing its effectiveness"). Similarly, regional human rights conventions require the determination of rights and obligations "within a reasonable time". See, for example, ECHR, art 6(1); American Convention on Human Rights, art 8(1).

65 See, for example, UnGA, 'Basic Principles', 2005, princ 17 (encouraging states to provide "effective mechanisms for the enforcement of reparation judgments"); International Commission of Jurists 2018, 81 ("If the judicial power lacks the means to carry out its judgments, the remedy cannot be considered to be effective"); Shelton 2015, 94 (discussing jurisprudence of the African Commission on Human and Peoples' Rights, which requires remedies that are "sufficient, i.e. capable of redressing the violation" and not "discretionary"); Schmitt 2017, 112 (emphasizing the importance of a tribunal with "the power to issue binding decisions which may not be altered by non-judicial authorities").

66 See, for example, ICJ, Avena Case 2004, para 119 ("reparation in an adequate form' varies 'depending on the concrete circumstances surrounding each case and the precise nature and scope of the injury"); ILA 2004, 35 ("With regard to the potential [substantive] outcome of remedies, there seems to be a connection between the identity of the party seeking redress, the kind of accountability involved, and the forum before which the remedial action has been brought").

67 See Shelton 2015, 32 ("The law of state responsibility [...] contains useful precedents for evaluating the nature and scope of remedies afforded in state practice"); see also ILC, 'Draft Articles on Responsibility of States for Internationally Wrongful Acts' 2001, arts 34-39 (addressing forms of reparation for injury, including restitution, compensation, and satisfaction).

68 Shelton 2015, 19, 33-34, 298, 307 (noting that restitution is the "preferred remedy" among regional human rights courts) and 384 .

69 Ibid, 19 and 315 (describing compensation as "a substitute remedy").

70 Ibid, 42-43, 394-397; see, for example, UNGA, 'Basic Principles' 2005, princ 18 and 21 (including rehabilitation as a potential form of redress); HRC, 'General Comment No 31', para 
public exposure of the truth. ${ }^{71}$ For grave breaches of human rights, the obligation to afford an effective remedy includes a duty of the State concerned to prosecute and punish the person responsible. ${ }^{72}$

Because the requirements of an effective remedy vary by context, and because States have significant discretion in shaping such remedies, it is difficult to discern consistent patterns in the type, amount, or frequency of reparations awarded. ${ }^{73}$ However, in her detailed survey of human rights remedies, Dinah Shelton has recognized "a growing consensus on minimum standards"74 of redress awarded by subsets of decision-making bodies. For instance, among international arbitral tribunals, compensation is "the most usual form of reparation",75 although such tribunals regularly award various forms of satisfaction as well. ${ }^{76}$ In the case of UN treaty bodies, such as the Human Rights Committee, recommendations for compensation are often accompanied by measures aimed at providing restitution and preventing reoccurrences. ${ }^{77}$ Lastly, while regional human rights courts differ widely in the specificity of their reparation decisions, they regularly consider compensation appropriate and are increasingly ordering or recommending restitution and satisfaction, when appropriate. ${ }^{78}$

16 (explaining that the reparations required under ICCPR art 2(3) can involve "rehabilitation and measures of satisfaction").

71 See Shelton $2015,22-24$ (discussing restorative justice principles) and 112-120 (discussing the right to truth); Bassiouni 2006, 275-276 (discussing the right to truth).

72 Francioni $2007,36-37$.

73 Shelton 2015, 106 (noting latitude afforded to states in awarding reparations under international human rights instruments), 143 (noting discretion afforded to international arbitrators in awarding reparations, but also arguing that scholarly criticisms that such practice is "inconsistent, even incoherent" are "overstated"), 383 (acknowledging another scholar's argument that "jurisprudence demonstrates the principle of the complete freedom of the judge or arbitrator, that there are no rules for reparations"), 376 (noting the "highly variable" and "unpredictable" awards by human rights tribunals).

74 Ibid, 19; see also ibid, 298 and 314 (noting consensus among international human rights bodies that restitution is the preferred remedy, but compensation, rehabilitation and satisfaction may be afforded as a substitute).

75 Ibid, 146.

76 Ibid, 159 (noting that international arbitrators often award "[p]ecuniary satisfaction" and have begun to view declaratory judgments as another form of satisfaction).

77 Ibid, 196-200, 306 (noting various types of restitution recommended by the HRC) and 321 (noting that UN treaty bodies "often call for compensation [...] but never quantify the amount due").

78 Ibid, 205-232 (discussing the ECtHR, which "continues to insist that it is for the states to choose the method of remedying the violation" but has "moved toward more of an emphasis on non-repetition of the violation and on restitution", as well as the IACtHR, which frequently orders compensation and is increasingly insisting that states publicly acknowledge violations), 307 (noting that both the European and Inter-American courts "now 
In sum, effective remedies are not 'one size fits all'. This point is especially important in evaluating how obligations to afford such remedies apply to international organizations.

\section{International Organizations' Obligations to Provide Effective Remedies}

The authors of this chapter are not the first to suggest that the customary international law obligation to provide effective remedies extends beyond States to international organizations. ${ }^{79}$ This chapter emphasizes three points, however, that have not garnered adequate attention. First, international organization are not simply passive recipients of customary international law rules; they have an active role to play in developing the rules that bind them. Second, in some cases, international organizations' obligations with respect to effective remedies might diverge from States' obligations. Just as distinct rules govern treaties to which international organizations are parties and the international responsibility of international organizations, so too there may be-or there may yet emerge-rules concerning effective remedies that are particular to international organizations. Third, the applicable rules may in some cases be further adapted for the circumstances of individual organizations through the development of lex specialis.

With the express support of a number of States and some international organizations, the ILC recently affirmed that international organizations can directly contribute to the development of customary international law. ${ }^{80}$ As the ILC put it, in certain cases, the practice and opinio juris of international

indicate that restitution is the preferred remedy where this is possible"), $385^{-3} 88$ (discussing evolution of the ECtHR's reparations awards) and 396-399 (discussing the wide range of the IACtHR's orders requiring satisfaction and guarantees of non-repetition).

79 See, for example, Benvenisti, The Law of Global Governance 2014, 110-111 (proposing that international organizations are "subject to at least basic human rights norms that require them to comply with procedural and due process obligations toward affected individuals"); Bradlow, 'Shield as a Sword' 2017, 60-61; ILA 2004, 33 (noting that "[a]s a general principle of law and as a basic international human rights standard, the right to a remedy also applies to Ios in their dealings with states and non-state parties' and 'may be seen as a norm of customary international law"); Schmitt 2017, 118 (“[A] customary law to establish administrative dispute settlement mechanisms is progressively emerging for international organizations").

8o Daugirdas, 'Creation of Customary International Law' forthcoming, 32. 
organizations "as such" may give rise or attest to customary international law rules. $^{81}$

There are several key areas of practice by international organizations, as such, that are directly relevant to establishing and assessing possible customary international law rules concerning effective remedies for violations of individuals' rights under international human rights law. Most, if not all, international organizations have established access to administrative tribunals to resolve employment disputes. These tribunals were established at least in part to vindicate individual rights under international law. ${ }^{82}$ The Security Council established the Ombudsperson for the Al-Qaida and ISIL sanctions regime following successful legal challenges and widespread criticism that the sanctions regime violated the human rights of designated individuals. ${ }^{83}$ And the Kosovo Human Rights Advisory Panel was specifically established to examine alleged violations of human rights by the UN Mission in Kosovo. ${ }^{84}$

This practice by international organizations could contribute to the development of customary international law rules regarding effective remedies that apply to States and international organizations alike - but it may also, or alternatively, contribute to the development of rules that apply only to international organizations, or only to subsets of them. There is room for the emergence of such particularized rules with respect to international organizations' obligations to provide effective remedies.

In its recent work on identifying rules of customary international law, the ILC affirmed the category of "particular customary international law" rules

$81 \quad$ ILC, 'Draft Conclusions on Identification of Customary International Law' 2018, concl 4; see also Daugirdas, 'Creation of Customary International Law' forthcoming, 1 (arguing this view is correct and supplying a fuller rationale for this conclusion).

82 See, for example, ILC, 'Comments and Observations' 2004, 31 ("The area in which the OAS has had to respond to claims alleging violation of international law is labour relations. Indeed, the Organization's decisions to establish an Administrative Tribunal in 1971 was, in part, based on the need to provide a forum for adjudicating those claims consistent with international standards of due process and additional standards established by the International Labor Organization"); Amerasinghe 1982 ("A second reason for the establishment of the [administrative] tribunal is [...] a principle accepted in many national legal systems and reaffirmed in the Universal Declaration of Human Rights. This principle requires that where administrative power is exercised there should be available machinery, in the event of disputes, to accord a fair hearing and due process to the aggrieved party"); Kwakwa 2010 (addressing the "human rights obligations of international organizations vis-à-vis their staff members" and responding to criticisms that existing mechanisms for resolving disputes with staff members fail to satisfy those obligations).

83 See Unsc, 'Ombudsperson to the ISIL'.

84 Human Rights Advisory Panel, 'Kosovo' 2016, 3. 
that bind only a limited number of States, excluding those States that do not participate in the practice or assent to be bound by it. ${ }^{85}$ The Commission has limited its discussion to particular customary law that has emerged, or might emerge, among groups of States linked by geography or by common cause, interest, or activity. ${ }^{86}$ This concept can likewise apply to international organizations as a category, or even to subcategories of international organizations. ${ }^{87}$ Particular customary international law rules can thus account for differences between States and international organizations, as well as differences among international organizations. This kind of tailoring is especially appropriate in the context of obligations to provide effective remedies.

One important way that international organizations' obligations may differ from those of States concerns the scope of international organizations' obligations to provide effective remedies. Specifically, international organizations' obligations may be broader than States' obligations in that they apply not only to violations of human rights, but also to other instances where international organizations cause harm to private individuals. ${ }^{88}$

Two main bodies of practice support this claim. First, as noted above, some international organizations have express treaty obligations to develop alternative dispute settlement mechanisms when legal process is blocked in national courts on account of the organizations' jurisdictional immunities. ${ }^{89}$ For example, the 'Convention on the Privileges and Immunities of the United Nations' (General Convention) and the 'Convention on the Privileges and Immunities of the Specialized Agencies' (Specialized Agencies Convention) contain nearidentical language in this regard. Article VIII, Section 29 of the former provides:

85 ILC, 'Draft Conclusions on Identification of Customary International Law' 2018, concl 16 and related comm.

86 Ibid.

87 Daugirdas, 'Creation of Customary International Law' forthcoming, 10-11 (suggesting that particular customary international law rules might emerge that apply specifically to international financial organizations).

88 In some cases, States have treaty obligations to provide compensation for lawful activities that cause harm. See, for example, Ronzitti 2007, 115; Guttinger 2010.

89 General Convention, art VIII, s 29; Specialized Agencies Convention, art IX, s 31; see also Berenson 2012, 139 (describing multilateral and bilateral agreements that the Organization of American States has concluded); Reinisch, 'Immunity' 2008, 288 (describing the International Atomic Energy Agency's headquarters agreement with Austria). 
The United Nations shall make provisions for appropriate modes of settlement of:

(a) Disputes arising out of contracts or other disputes of a private law character to which the United Nations is a party;

(b) Disputes involving any official of the United Nations who by reason of his official position enjoys immunity, if immunity has not been waived by the Secretary-General. ${ }^{90}$

Implementing these obligations, the United Nations has established procedures for handling, among other things, disputes arising out of commercial agreements, including contracts and lease agreements; tort claims arising from acts within the Headquarters district in New York; and claims arising from accidents involving vehicles operated by UN personnel for official purposes. ${ }^{91}$

The second body of relevant practice includes the World Bank Inspection Panel (WBIP) and similar institutions at other multilateral development banks. ${ }^{92}$ At the World Bank, this inspection mechanism is open to individuals who have been harmed by the Bank's violations of certain of its own policies and procedures. ${ }^{93}$ These 'safeguard policies' address a range of environmental and social issues - but there is no explicit safeguard policy addressing human rights. ${ }^{94}$ Violations of these policies might constitute violations of international law-but there is no requirement that they do so. Notably, there are no treaty provisions that expressly demand the establishment of the WBIP or other similar mechanisms; instead, they have been established and refined based on

9o General Convention, art viII, s 29; Specialized Agencies Convention, art IX, s 31.

91 UN, 'Report of the Secretary-General' 1995; see also Difference Relating to Immunity from Legal Process Verbatim Record (1998), paras 5-14 (explanation by the UN Legal Counsel of the remedial regime established by art VIII, $\mathrm{s} 29$ of the Convention).

92 For a description and comparison of these mechanisms, see Bradlow, 'Comparative Study' 2005 .

93 World Bank Inspection Panel Res No IBRD 93-10 \& Res No IDA 93-6, 22 September 1993, para 12 ("The affected party must demonstrate that its rights or interests have been or are likely to be directly affected by an action or omission of the Bank as a result of a failure of the Bank to follow its operational policies and procedures with respect to the design, appraisal and/or implementation of a project financed by the Bank [...] provided in all cases that such failure has had, or threatens to have, a material adverse effect").

94 World Bank Operational Manual, op 4.10. There is a reference to human rights in Operational Policy 4.10 regarding Indigenous Peoples, which notes at the outset that the policy "contributes to the Bank's mission of poverty reduction and sustainable development by ensuring that the development process fully respects the dignity, human rights, economies, and cultures of Indigenous Peoples". 
'practice and necessity'. ${ }^{95}$ And although they are not identical, the resulting inspection mechanisms converge across institutions to a significant degree. ${ }^{96}$

While particular customary international law can tailor rules to international organizations as a group, or to certain groups of international organizations, it bears emphasis that there is some further room for tailoring obligations to individual organizations. As noted above, customary international law rules bind international organizations as a default matter; as a result, member States have some capacity to alter the applicable customary international law rules by creating lex specialis. ${ }^{97}$ Because States are not permitted to alter customary international law rules on human rights to the detriment of beneficiaries, this route is not available to eliminate altogether the obligation to afford effective remedies. ${ }^{98}$ This route is available, however, to further specify the details of individual organizations' obligations to afford effective remedies.

Whether international organizations' practice with respect to providing alternative remedies adds up to a rule of particular customary international law ultimately depends not only on the consistency of this practice across international organizations (or some subset of international organizations), but also on the motivations for that practice-specifically, whether it is undertaken with a sense of legal obligation, or opinio juris. For this reason, it matters not only what international organizations do, but what they say about why they do it. The next section urges international organizations to say more.

\section{Breaking the Silence}

International organizations ought to not only ensure that they have in place dispute settlement mechanisms that satisfy the procedural and substantive requirements of effective remedies-but also acknowledge customary international law obligations to do so. By publicly engaging in discourse about their

95 Boisson de Chazournes 2012, 174.

96 Ibid.

97 See Daugirdas, 'How and Why' 2016, 347-348, and accompanying text for n 40-41.

98 Koskenniemi 2006, paras 108-109; Bradley and Gulati 2010, 211-212; IBRD Articles of Agreement, art IV, $\mathrm{s} 10$. This point is especially important when considering the impact on customary obligations, if any, of language prohibiting political activity in the constituent instruments of numerous multilateral development banks. For the World Bank, the relevant language is that, "The Bank and its officers shall not interfere in the political affairs of any member; nor shall they be influenced in their decisions by the political character of the member or members concerned. Only economic considerations shall be relevant to their decisions, and these considerations shall be weighed impartially in order to achieve the purposes stated in Article I". 
international obligations to afford effective remedies, international organizations can actively shape the development of customary international law in this area, counter the narrative that their immunities place them above the law, and bolster their reputations and their legitimacy.

International organizations' effectiveness depends, in part, on their reputations and perceptions of their legitimacy. ${ }^{99}$ One important aspect of international organizations' reputations - and by extension their legitimacy — is their reputation for legality. ${ }^{100}$ In a narrower sense, a reputation for legality depends on compliance with legal obligations. Perhaps one motivation for international organizations' silence with respect to their obligations to afford effective remedies (and their obligations under customary international law more generally) is the desire to preserve their reputations for legality. Just as, for example, States might avoid putting their reputations for compliance on the line by becoming parties to certain treaties, so too might international organizations try to avoid risking their reputations for compliance by not acknowledging obligations under customary international law.

Such an approach is misguided and ultimately self-defeating. To start, international organizations do not insulate themselves from charges that they are non-compliant by not acknowledging the existence of binding obligations in the first place. Thus, for example, in the course of recent litigation challenging the immunity of the International Finance Corporation (IFC), which ultimately reached the United States Supreme Court in the case Jam vIFC, Daniel Bradlow argued that the Compliance Advisor Ombudsman - the IFC's variation of the WBIP - does not qualify as an effective remedy. ${ }^{101}$ Moreover, in a broader sense, a reputation for legality depends on adherence to rule-of-law values

99 See Boon 2016, 375 (“[A]s a matter of public legitimacy, the UN must not be seen to be above the law"); Daugirdas, 'Reputation and Responsibility' 2014, 1007-1009. For examples in the popular press, see Yeoman, 27 September 2018; Rosen, 26 February 2013 ("The organization is functionally above the law-and victims of Haiti's cholera outbreak aren't the only ones paying the price"); see also Daugirdas, 'Reputation as a Disciplinarian' 2019, $225^{-235}$.

100 Daugirdas, 'Reputation and Responsibility' 2014, 1012-1016; Daugirdas, 'Reputation as a Disciplinarian' 2019, 228.

101 Bradlow, 'Amicus Brief', 7 August 2016, 17-18 and 22-23 (arguing that the Compliance Advisor Ombudsman meets some but not all of the criteria for effective remedies: "It is accessible to all qualifying stakeholders and it is reasonably fair, although the complainant is not necessarily given an opportunity to respond to the evidence and arguments presented by the IFC's management. It is not clearly impartial because the IFC's Board and senior management retain final decision making powers. Moreover, it is not independent because the Compliance Advisor Ombudsman is appointed by and reports to the senior management of the IFC. In addition, it does not necessarily provide the complainants with a meaningful remedy because its findings and recommendations are non-binding"). 
and norms. ${ }^{102}$ When international organizations fail to provide effective remedies, they are vulnerable to the charge that they are above the law, or that they are abusing their immunities - and as a result, their reputations for legality in the broader sense remain at risk..$^{103}$

Separately, although the trend is not universal, courts that are asked to uphold the immunity of international organizations are increasingly concerned not just with the existence - but also with the adequacy — of alternative dispute settlement mechanisms. ${ }^{104}$ Sometimes the motivation for evaluating the adequacy of those mechanisms is ensuring compliance with the State's own human rights obligations. Thus, for example, in Waite and Kennedy v Germany, the European Court of Human Rights held that,

\begin{abstract}
[A] material factor in determining whether granting [the European Space Agency] immunity from German jurisdiction is permissible under the [European Convention on Human Rights] is whether the applicants had available to them reasonable alternative means to protect effectively their rights under the Convention. ${ }^{105}$
\end{abstract}

In other cases, the adequacy of alternative mechanisms may affect the policy decisions of national governments. When Jam $v$ IFC reached the US Supreme Court, only one justice-Justice Breyer-was willing to uphold the absolute immunity of the IFC. ${ }^{106}$ Justice Breyer likewise emphasized the importance of adequate dispute settlement mechanisms. He observed that, if the alternative

102 Hurd 2005 (describing the serious threat that Libya posed to the UN Security Council in part by portraying it as acting inconsistently with the rule of law in imposing sanctions in the wake of the bombing of Pan Am 103).

103 Berenson 2012, 145 (noting that abuse of immunities occurs "when international organizations and their officials do not provide alternative independent means for recourse for claims against them"); see also Boon 2016, 375 (“[A]s a matter of public legitimacy, the UN must not be seen to be above the law"); Daugirdas, 'Reputation and Responsibility' 2014, 1007-1009. For examples in the popular press, see Yeoman, 27 September 2018; Rosen, 26 February 2013 ('The organization is functionally above the law-and victims of Haiti's cholera outbreak aren't the only ones paying the price').

104 See Reinisch, 'Immunity' 2008, 285 (observing that, when adjudicating cases involving the immunity of international organizations, "more and more national courts are [...] looking at the availability and adequacy of alternative dispute settlement mechanisms"); Martha 2012, 119-120 (describing such cases in Argentine courts).

105 ECtHR, Waite and Kennedy v Germany 1999, para 68. See also Singer 1995, 90-95; Treichl 2019, 417-429 (describing relevant case law subsequent to Waite and Kennedy).

106 US Supreme Court, Jam VIFC 2019, dissenting opinion of Justice Breyer. 
mechanisms proved inadequate, the relevant statute allowed the US executive branch to set aside the organization's immunity. ${ }^{107}$

International organizations that can credibly characterize their alternative mechanisms as satisfying customary international law standards with respect to the provision of effective remedies will be better able to defend those mechanisms as 'adequate' - and thereby discourage national governments and national courts from evaluating adequacy on the basis of idiosyncratic or 'chauvinistic' criteria. ${ }^{108}$ Particular customary international law regarding effective remedies can supply standards that are not only international, but also tailored to the specific context of international organizations.

As an example of constructive participation in the discourse about effective remedies, consider former UN Secretary-General Kofi Annan's commentary regarding the essential features of mechanisms for challenging the continued imposition of targeted sanctions by the Security Council. The routes available for challenging such sanctions have evolved over time. Initially, targeted individuals and entities were able to seek delisting only through their national governments. ${ }^{109}$ Starting in 2006, they were able to make such demands directly through a 'focal point'.110 For what is today the targeted sanctions regime for ISIL and Al-Qaida, targeted individuals and entities may present petitions for delisting to an Ombudsperson appointed by the UN Secretary-General. ${ }^{111}$ The Ombudsperson then gathers information from various sources and engages with the petitioner to explain the process and collect additional information if needed; ultimately the Ombudsperson makes a recommendation to the Security Council to maintain or terminate the listing. ${ }^{112}$ If the Ombudsperson recommends delisting, the individual or entity will be removed from the sanctions list unless, within 60 days, a committee of the Security Council members decides, by consensus, to retain the listing - or if the Security Council makes a decision to maintain the listing. To date, none of the Ombudsperson's recommendations have been overturned. ${ }^{113}$

Kimberly Prost, who served as the first Ombudsperson, has argued that the appropriate standard for evaluating the Ombudsperson process was articulated by former UN Secretary-General Kofi Annan. In 2006, Annan set out what

\footnotetext{
107 Ibid.

108 Prost 2017, 224.

109 Kingsbury and others 2005, 32 and 34.

110 Forcese and Roach 2010, 225 (recounting the evolution of the focal point and ombudsperson mechanisms).

111 UNSC Res 1904, 17 December 2009, paras 20-21; UnSC, 'Ombudsperson to the ISIL'.

112 Ibid.

113 UNSC, 'Ombudsperson to the ISIL'.
} 
were, in his view, the minimum standards for ensuring that the procedures for listing and delisting individuals were "fair and transparent". ${ }^{114}$ On the procedural side, Annan explained, listed persons have a "right to be heard, via submissions in writing, within a reasonable time by the relevant decision-making body [...] as well as the right to be assisted or represented by counsel".15 In addition, listed persons have a "right to review by an effective review mechanism", where effectiveness "will depend on its impartiality, degree of independence and ability to provide an effective remedy, including the lifting of the measure and/or, under specific conditions to be determined, compensation". ${ }^{116}$

Prost praised Annan's enunciation of these requirements as "carefully crafted, taking into account realities of the practice of the Security Council and what might be achievable in that very particular context". ${ }^{\prime 17}$ As for how the Ombudsperson mechanism measures up, Prost argued that the Ombudsperson mechanism "as designed and operating in practice to date fulfills the fundamental requirements of an effective review mechanism; one which provides an equivalent protection to judicial review by an independent tribunal".118 The UN Secretary-General's intervention didn't preclude further debate about or criticism of the adequacy of the Ombudsperson mechanism. ${ }^{119}$ But, as Prost points out, Annan helpfully defined standards that were specifically tailored for an international organization, and that could-and ought to-anchor evaluations of the Ombudsperson mechanism.

When it comes to defining what constitutes an effective remedy in the specific context of international organizations, another valuable resource is the literature on global administrative law. This field focuses on "the mechanisms, principles, practices, and supporting social understandings that promote or

\footnotetext{
114 UNSC, '5474th Meeting' 22 June 2006, 5.

115 Ibid.

116 Ibid.

117 Prost 2017, 232.

118 Ibid, 233 .

119 ECJ, European Commission et al. $v$ Yassin Abdullah Kadi 2013, paras 133-134. Most notably, in reviewing measures to implement Security Council sanctions, the Court of Justice for the European Union declined to accord any significance to the existence of the Ombudsperson mechanism because that mechanism did not guarantee effective judicial protection as it had been defined by the European Court of Human Rights, which asks whether the person concerned can "obtain a declaration from a court, by means of a judgment ordering annulment whereby the contested measure is retroactively erased from the legal order and is deemed never to have existed, that the listing of his name, or the continued listing of his name, on the list was vitiated by illegality, the recognition of which may reestablish the reputation for that person or constitute for him a form of reparation for the non-material harm he has suffered".
} 
otherwise affect the accountability of global administrative bodies". ${ }^{20}$ These principles and mechanisms include ex post review by judicial or other similar bodies $^{121}$ —as well as other complementary principles and mechanisms, such as transparency, reason-giving, and participation in decision-making. ${ }^{122}$ Scholarship in this area has devoted considerable attention to review mechanisms like the WBIP, the UN Security Counsel Ombudsperson, and the IFC Compliance Advisor Ombudsman. ${ }^{123}$ For example, Benjamin Saper argues that the IFC Compliance Advisor Ombudsman has advanced the interests of individuals affected by projects funded by the IFC by increasing the IFC's responsiveness to these individuals - even though the Compliance Advisor Ombudsman lacks the authority to halt projects or to award compensation to injured individuals. ${ }^{124}$

Notably, while global administrative law can inform evaluations of the scope and content of customary obligations to provide effective remedies, the recognition of such obligations can also advance the aims of global administrative law. While scholars in the field have developed a normative case for the adoption of certain principles and mechanisms, they have devoted less attention to arguing that international organizations have legal obligations to do so. ${ }^{125}$ That said, they have recognized that locating such obligations in traditional sources of international law "may be the best way to maintain legal predictability and to sustain rule of law values in international relations".126 Customary international law obligations to provide effective remedies supply just that: a way to cement certain global administrative law principles in a traditional source of binding law that applies to international organizations.

To be sure, by engaging in discourse about their obligations to afford effective remedies, international organizations would face certain risks and costs.

\footnotetext{
120 Kingsbury and others 2005, 17.

121 Ibid, 39-40; Benvenisti, The Law of Global Governance 2014, 240-285.

122 Kingsbury and others 2005, 37-39; Stewart 2014 (distinguishing ex post accountability mechanisms from other related and complementary mechanisms).

123 See Kingsbury and others 2005, 39-40; Benvenisti, The Law of Global Governance 2014, 240-285; Saper 2012.

124 Saper 2012.

125 To the extent scholars have tried to ground global administrative law principles in binding sources of law, they have not focused on traditional sources and have not coalesced around any unified theory. Compare Benvenisti, The Law of Global Governance 2014, 91137 (suggesting that such principles are binding based on 'rule of law' principles, international human rights law, or trusteeship) with Kingsbury and others 2005, 29 (proposing a "revived version of ius gentium").

126 Kingsbury 2005, 148.
} 
First, organizations will be constrained by their own legal arguments. ${ }^{127}$ Most importantly, having acknowledged legal obligations to afford effective remedies, international organizations will need to confront the possibility that their existing accountability mechanisms fall short of any plausible interpretation of those obligations - and that those mechanisms need to be reformed accordingly. In addition, acknowledging customary international law obligations to provide effective remedies may increase pressure on international organizations to recognize other customary obligations, particularly obligations based on international human rights law. International organizations may also confront increased demands by individuals for compensation. At the end of the day, however, international organizations' current approach is sure to be even more costly by eroding their legitimacy and support for their immunities.

Human rights advocates might raise a different objection - that by exhorting international organizations to shape the customary international law rules that bind them, we are inviting international organizations to minimize their obligations. In our view, this risk is not significant. One feature of legal arguments is that they are not infinitely elastic: implausible arguments about, for example, what constitutes an effective remedy will encounter vociferous objections from scholars, activists and UN special rapporteurs, among others. ${ }^{128}$ Separately, there are countervailing advantages to international organizations' express participation in discourse about their international obligations. By acknowledging international obligations with respect to effective remedies, international organizations would limit their discretion to 'backslide' by paring back or eliminating such mechanisms. This consequence is important in light of some member States' limited enthusiasm for them. ${ }^{129}$ Finally, participation in the development of norms can bolster compliance with those norms. Anthea Roberts and Sandesh Sivakumaran made this point when addressing parallel concerns regarding their proposal that armed opposition groups be

127 See generally Johnstone 2011. For example, Johnstone points out that a government's (or, by extension, an international organization's) rhetorical acceptance of a norm creates a "discursive opening" for critics to challenge its compliance with that norm, eventually inducing governments (or, by extension, international organizations) "to match deeds with words". Ibid, 27.

128 Daugirdas, 'Reputation and Responsibility' 2014, 998 (noting the range of actors who participate in transnational discourse in various forums about international organizations' legal obligations and compliance with those obligations, and noting that that these actors can "initiate and perpetuate discussion, they can contribute new legal arguments or relevant facts, and they can evaluate legal arguments").

129 Bradlow, 'Multilateral Development Banks' 2019, 29-30 (noting the persistence of tensions that independent accountability mechanisms created between borrower and creditor member states of multilateral development banks). 
allowed to participate in the creation of international humanitarian law. ${ }^{130}$ Giving ordinarily excluded groups a role in lawmaking affords them a sense of ownership in the law, which makes it psychologically easier for them to accept and respect those laws. ${ }^{131}$ Such participation can also help to assure that the rules that are established are rules with which regulated entities can realistically comply. ${ }^{132}$

As international organizations affect individuals in ever-expanding ways, ${ }^{133}$ it is increasingly apparent that alternative dispute resolution mechanisms are needed to protect and redress those harmed by these international actors. This chapter urges international organizations not only to establish such mechanisms, but also to acknowledge customary international law obligations to provide effective remedies.

There are several benefits to recognizing a customary international law obligation on international organizations to provide effective remedies. From the perspective of international organizations, it offers a way to protect their existing immunities and to develop customary norms that are tailored specifically to them. From the perspective of international human rights law, it offers a way to apply human rights law to powerful, non-State actors-and increases the likelihood that those obligations will be implemented. And from the perspective of global administrative law, a customary obligation offers a way to cement accountability-promoting principles in a traditional source of binding law.

Recognizing this customary obligation is, of course, not costless. It may expose international organizations to increased pressures and demands for compensation, and it might allow international organizations to water down the content of their obligations. The authors of this chapter are not blind to these costs. But we believe that the risks and costs of the status quo are even greater.

\footnotetext{
130 Roberts and Sivakumaran 2012, 126-127 and 151.

131 Ibid, 127; Blokker 2017, 10 ("Why should [international organizations] fully comply with rules of customary international law without being able to fully participate in its development?").

132 Roberts and Sivakumaran 2012, 139; see also Prost 2017, 232 (noting this advantage with respect to the minimum standards articulated by former Secretary-General Annan in the context of Security Council targeted sanctions).

133 Kingsbury and others 2005, 23-25.
} 


\section{Reference List}

Aloeboetoe v Suriname (Reparations) Series A No 15 (IACtHR, 10 September 1993).

Alvarez J, 'Review of International Organizations and Their Exercise of Sovereign Powers' (2007) 101 American Journal of International Law 674.

Amerasinghe C F, 'The World Bank Administrative Tribunal' (1982) 31 International and Comparative Law Quarterly 748.

American Convention on Human Rights (adopted 22 November 1969, entered into force 18 July 1978) 1144 UNTS 123.

Articles of Agreement of the International Bank for Reconstruction and Development (22 July 1944) 2 UNTS 134.

Asian Infrastructure Investment Bank, 'The Role of Law at AIIB' (AIIB) < www.aiib.org/ law $>$ accessed 7 February 2020.

Avena and Other Mexican Nationals (Mexico v United States of America) [2004] ICJ Rep 12 (Avena Case).

Bassiouni C, 'International Recognition of Victims' Rights' (2006) 6 Human Rights Law Review 203.

Benvenisti E, 'The Applicability of the Law of Occupation to UN Administration of Foreign Territory' (2019) University of Cambridge Faculty of Law Legal Studies Research Paper 36/2019 <https://papers.ssrn.com/sol3/papers.cfm?abstract_id=349 $8872>$ accessed 6 February 2020.

Benvenisti E, The Law of Global Governance (Hague Academy of International Law 2014).

Berenson W, 'Squaring the Concept of Immunity with the Fundamental Right to a Fair Trial: The Case of the OAs' (2012) 3 World Bank Legal Review 133.

Blokker N, 'Editorial: International Organizations and Customary International Law: Is the International Law Commission Taking International Organizations Seriously?' (2017) 14 International Organizations Law Review 1.

Boisson de Chazournes L, 'Partnerships, Emulation, and Coordination: Toward the Emergence of a Droit Commun in the Field of Development Finance' (2012) 3 World Bank Legal Review 173 .

Boon K, 'The United Nations as Good Samaritan: Immunity and Responsibility' (2016) 16 Chicago Journal of International Law 341.

Bradley C and Gulati M, 'Withdrawing from International Custom' (2010) 120 Yale Law Journal 202.

Bradlow D, 'Brief of Amicus Curiae in Support of Plaintiffs-Appellants, Jam v International Finance Corp, DC Cir No 16-7051' (filed 17 August 2016).

Bradlow D, 'Multilateral Development Banks, Their Member States and Public Accountability: A Proposal' (2019) 11 Indian Journal of International Economic Law 21. 
Bradlow D, 'Private Complainants and International Organizations: A Comparative Study of the Independent Inspection Mechanisms in International Financial Institutions' (2005) 36 Georgetown Journal of International Law 403.

Bradlow D, 'Using a Shield as a Sword: Are International Organizations Abusing Their Immunity?' (2017) 31 Temple International and Comparative Law Journal 45.

Brunnée J, 'International Legal Accountability Through the Lens of the Law of State Responsibility' (2005) 36 Netherlands Yearbook of International Law 21.

Case Concerning the Factory at Chorzów (Jurisdiction) [1927] PCIJ Series A, No 9.

Charter of Fundamental Rights of the European Union (entered into force 1 December 2009) 2012/C 326/02.

Chinkin C, Third Parties in International Law (oup 1993).

Committee on the Rights of the Child, 'General Comment No 16 on State Obligations Regarding the Impact of the Business Sector on Children's Rights' (17 April 2013) $\mathrm{CRC} / \mathrm{C} / \mathrm{GC} / 16$.

Convention on the Elimination of All Forms of Discrimination Against Women (adopted 18 December 1979, entered into force 3 September 1981) 1249 UNTS 13.

Convention on the Elimination of All Forms of Racial Discrimination (adopted 21 December 1965, entered into force 4 January 1969) 66o UNTS 195.

Convention on the Privileges and Immunities of the Specialized Agencies (adopted 21 November 1947, entered into force 2 December 1948) 33 UNTS 261.

Convention on the Privileges and Immunities of the United Nations (adopted 13 February 1946, entered into force 17 September 1946) 1 UNTS 15 .

Daugirdas K, 'How and Why International Law Binds International Organizations' (2016) 57 Harvard International Law Journal 325.

Daugirdas K, 'International Organizations and the Creation of Customary International Law' (forthcoming) European Journal of International Law <https://papers.ssm. $\mathrm{com} /$ sol3/papers.cfm?abstract_id=3160229 $>$ accessed 6 February 2020.

Daugirdas K, 'Reputation and the Responsibility of International Organizations' (2014) 25 European Journal of International Law 991.

Daugirdas K, 'Reputation as a Disciplinarian of International Organizations' (2019) 113 American Journal of International Law 221.

Difference Relating to Immunity from Legal Process of a Special Rapporteur of the Commission on Human Rights Verbatim Record CR/98/17 (10 December 1998).

Effect of Awards of Compensation Made by the United Nations Administrative Tribunal (Advisory Opinion) [1954] ICJ Rep 47.

European Commission et al. $v$ Yassin Abdullah Kadi European Court of Justice Judgment on Joined Cases C-584/10 P, C-593/10 P and C-595/10 P (18 July 2013).

European Convention for the Protection of Human Rights and Fundamental Freedoms (adopted 4 November 1950, entered into force 3 September 1953) 213 UNTS 221. 
Forcese C and Roach K, 'Limping into the Future: The U.N. 1267 Terrorism Listing Process at the Crossroads' (2010) 42 George Washington International Law Review 217.

Francioni F, 'The Rights of Access to Justice Under Customary International Law' in Francioni F (ed) Access to Justice as a Human Right (OUP 2007).

Frowein J, 'Ius Cogens' (Max Planck Encyclopedias of International Law, 2013) < https:// opil.ouplaw.com/view/10.1093/law:epil/978019923169o/law-978019923169o-e1437> accessed 5 February 2020.

Guttinger P, 'Allocation of Responsibility for Harmful Consequences of Acts Not Prohibited by International Law' in Crawford J and others (eds) The Law of International Responsibility (OUP 2010).

Handl G, Multilateral Development Banking: Environmental Principles and Concepts Reflecting General International Law and Public Policy (Kluwer Law International 2001).

Hannum H, 'The Status of the Universal Declaration of Human Rights in National and International Law' (1996) 25 Georgia Journal of International and Comparative Law 287.

Human Rights Advisory Panel, 'Final Report, History and Legacy, Kosovo, 2007-2016' (30 June 2016).

Human Rights Committee, 'General Comment No. 31: The Nature of the General Legal Obligation Imposed on State Parties to the Covenant' (26 May 2004) CCPR/C/21/ Rev $1 /$ Add 13.

Human Rights Committee, 'General Comment No. 32: Article 14, Right to Equality Before Courts and Tribunals and to Fair Trial' (23 August 2017) CCPR/C/GC/32.

Hurd I, 'The Strategic Use of Liberal Internationalism' (2005) 59 International Organization 495 .

International Commission of Jurists, The Right to a Remedy and Reparation for Gross Human Rights Violations: A Practitioner's Guide No 2 (revised edn, International Commission of Jurists 2018).

International Covenant on Civil and Political Rights (adopted 16 December 1966, entered into force 23 March 1976) 999 UnTs 171.

International Law Association, 'Berlin Conference (2004) Accountability of International Organisations' (2004) 1 International Organizations Law Review 221.

International Law Commission, 'Draft Articles on Responsibility of International Organizations, with Commentaries' (2011) UN Doc A/66/10.

International Law Commission, 'Draft Articles on Responsibility of States for Internationally Wrongful Acts, with Commentaries' (2001) UN Doc A/56/10.

International Law Commission, 'Draft Conclusions on Identification of Customary International Law, with Commentaries' (2018) UN Doc A/73/10.

International Law Commission, 'Responsibility of International Organizations: Comments and Observations Received from International Organizations' (25June 2004) UN Doc A/CN 4/545. 
International Law Commission, 'Responsibility of International Organizations: Comments and Observations Received from International Organizations' (1 May 2007) $\mathrm{UN}$ Doc A/CN 4/582.

Interpretation of the Agreement of 25 March 1951 Between the wHO and Egypt (Advisory Opinion) [1980] ICJ Rep 73.

Jam v International Finance Corporation 586 US (2019).

Johnstone I, The Power of Deliberation (OUP 2011).

Kingsbury B, 'The Administrative Law Frontier in Global Governance' (2005) 99 American Society of International Law Proceedings 143.

Kingsbury B and others, 'The Emergence of Global Administrative Law' (2005) 68 Law and Contemporary Problems 15.

Klabbers J, 'Sources of International Organizations' Law: Reflections on Accountability' in Besson S and D'Aspremont J (eds), The Oxford Handbook on the Sources of International Law (Oup 2017).

Koskenniemi M, 'Fragmentation of International Law: Difficulties Arising from the Diversification and Expansion of International Law' (13 April 2006) UN Doc A/CN 4/L 682.

Kwakwa E, 'An International Organization's Point of View' in Wouters J and others (eds), Accountability for Human Rights Violations by International Organizations (Intersentia 2010).

Lasco C, 'Repairing the Irreparable: Current and Future Approaches to Reparations' (2003) 10-2 Human Rights Brief 18.

Martha R S J, 'International Financial Institutions and Claims of Private Parties: Immunity Obliges' (2012) 3 World Bank Legal Review 93.

Prost K, 'Security Council Sanctions and Fair Process' in Van den Herik L (ed), Research Handbook on UN Sanctions and International Law (Edward Elgar 2017).

Reinisch A, 'Securing the Accountability of International Organizations' (2001) 7 Global Governance 131 .

Reinisch A, 'The Immunity of International Organizations the Jurisdiction of Their Administrative Tribunals' (2008) 7 Chinese Journal of International Law 285.

Roberts A and Sivakumaran S, 'Lawmaking by Nonstate Actors: Engaging Armed Groups in the Creation of International Humanitarian Law' (2012) 37 Yale Journal of International Law 107.

Ronzitti N, 'Access to Justice and Compensation for Violations of the Law of War' in Francioni F (ed), Access toJustice as a Human Right (OUP 2007).

Rosen A, 'How the U.N. Caused Haiti's Cholera Crisis - and Won't Be Held Responsible' The Atlantic (26 February 2013) <https://www.theatlantic.com/international/ archive/2013/02/how-the-un-caused-haitis-cholera-crisis-and-wont-be-heldresponsible/273526/> accessed 6 February 2020.

Saper B, 'The International Finance Corporation's Compliance Advisor/Ombudsman (CAO): An Examination of Accountability and Effectiveness from a Global 
Administrative Law Perspective' (2012) 44 NYU Journal of International Law and Politics 1279 .

Schmitt P, Access to Justice and International Organizations: The Case of Individual Victims of Human Rights Violations (Edward Elgar Publishing 2017).

Shelton D, Remedies in International Human Rights Law (3rd edn, OUP 2015).

Shihata I F I, The World Bank Inspection Panel: In Practice (1st edn, World Bank 1994).

Singer M, 'Jurisdictional Immunity of International Organizations: Human Rights and Functional Necessity Concerns' (1995) 36 Virginia Journal of International Law 53.

Skogly S, The Human Rights Obligations of the World Bank and the International Monetary Fund (Cavendish Publishing Ltd 2001).

Stewart R, 'Remedying Disregard in Global Regulatory Governance: Accountability, Participation, and Responsiveness' (2014) 108 American Journal of International Law 211.

Suzuki E and Nanwani S, 'Responsibility of International Organizations: The Accountability Mechanisms of Multilateral Development Banks' (2005) 27 Michigan Journal of International Law 177.

Treichl C, 'The Denial of Oral Hearings by International Administrative Tribunals as a Factor for Lifting Organizational Immunity before European Courts: A(nother) Critical View' (2019) 16 International Organizations Law Review 407.

UNGA, Basic Principles and Guidelines on the Right to a Remedy and Reparations for Victims of Gross Violations of International Human Rights Law and Serious Violations of International Humanitarian Law (adopted 16 December 2005) UN Doc $\mathrm{A} / \mathrm{RES} / 60 / 147$.

United Nations, 'Procedures in Place for Implementation of Article VIII, Section 29, of the Convention on the Privileges and Immunities of the United Nations adopted by the General Assembly on 13 February 1946: Report of the Secretary-General' (1995) UN Doc A/C 5/49/65.

United Nations Security Council, '5474th Meeting' (22 June 2006), UN Doc S/PV5474.

United Nations Security Council, 'Ombudsperson to the IsIL (Da'esh) and Al-Qaida Sanctions Committee' (United Nations Security Council) <www.un.org/securitycouncil/ombudsperson $>$ accessed 7 February 2020.

Universal Declaration of Human Rights (UNGA Res 217A (III), 10 December 1948) UN Doc A/810.

UNSC Res 1904 (17 December 2009) UN Doc S/RES/1904.

Verdirame G, The UN and Human Rights: Who Guards the Guardians? (Cambridge University Press 2011).

Vienna Convention on the Law of Treaties (adopted 23 May 1969, entered into force 27 January 1980) 1155 UNTS 331. 
Vienna Convention on the Law of Treaties Between States and International Organizations or Between International Organizations (adopted 21 March 1986, not yet in force) UN Doc A/CONF 129/15.

Waite and Kennedy v Germany App no 26o83/94 (ECtHR, 18 February 1999).

Wellens K, Remedies Against International Organizations (Cambridge University Press 2002).

World Bank Inspection Panel, Res No IBRD 93-10 \& Res No IDA 93-6 (22 September 1993).

World Bank, Operational Manual.

Yeoman B, 'Is the World Bank Group Above the Law?' The Nation (27 September 2018) $<$ https://www.thenation.com/article/is-the-world-bank-group-above-the-law/> accessed 6 February 2020. 